\title{
The genetic basis of infertility
}

\author{
Kavita Shah, Gayathri Sivapalan, Nicola Gibbons, Helen Tempest \\ and Darren K. Griffin* \\ Cell and Chromosome Biology Group, Department of Biological Sciences, Brunel University, \\ Uxbridge, Middlesex UB8 3PH, UK
}

Infertility is defined as the inability to conceive after one year of regular unprotected intercourse; approximately one in six couples wishing to start a family fall into this category. Although, in many cases, the diagnosis is simply 'unexplained', a variety of reasons including lack of ovulation, mechanical stoppage, sperm deficiencies and parental age have been implicated. It is difficult to assess accurately the overall magnitude of the contribution of genetics to infertility as most, if not all, conditions are likely to have a genetic component, for example susceptibility to infection. Nevertheless, a significant number of infertility phenotypes have been associated with specific genetic anomalies. The genetic causes of infertility are varied and include chromosomal abnormalities, single gene disorders and phenotypes with multifactorial inheritance. Some genetic factors influence males specifically, whereas others affect both males and females. For example, chromosome translocations affect both males and females, whereas Klinefelter syndrome and the subsequent infertility phenotype caused by it are specific to males. This article reviews current research in the genetic basis of infertility; gender-specific disorders and those affecting both sexes are considered.

Infertility is defined as the inability to conceive after one year of regular unprotected intercourse and accounts for one in six couples wishing to start a family. A healthy young couple in their mid-twenties has only a $20-25 \%$ chance of establishing a pregnancy in each cycle and thus a range of factors, each with different extents of genetic control, may influence their chances. Infertility can be hormonal, related to age, exercise, obesity or infectious disease; it can be immunological, psychological, result from surgery or blockage, or be associated with defined abnormalities in the gametes (for example aberrant semen parameters). Perhaps the most common 'cause' of infertility is simply 'unexplained' and this accounts for about $20 \%$ of couples (Uehara et al., 2001). It is difficult to assess accurately the genetic contribution to reduced fertility as most, if not all, of the above factors are likely to have a genetic component. For instance, susceptibility to infection, obesity and psychological problems and even the likelihood of having surgery may have some genetic basis, however small. Nevertheless, specific genotypes and karyotypes have been associated with infertility phenotypes and studies of specific genes in humans and model systems shed light on the nature of the polygenic and multifactorial basis of infertility.

*Correspondence

Email: darren.griffin@brunel.ac.uk

\section{Chromosome disorders: structural aberrations}

\section{Translocations}

Reciprocal translocations can lead to reduced fertility, spontaneous abortions or birth defects, depending on the chromosomes involved and the nature of the translocation. In autosome-autosome translocations, reduced fertility is mediated by the fact that the translocated chromosomes, in order to progress through meiosis, need to synapse through a pairing cross. This process can lead to infertility in several ways. First, the mechanics and time constraints imposed on the formation of such a quadrivalent can impede the meiotic process (Forejt, 1982). Second, the disjunction of the pairing cross is prone to the production of genetically unbalanced gametes. Third, asynaptic regions are common within the pairing cross and can lead to failure of meiosis and subsequently elimination of germ cells (Miklos, 1974). Fourth, there is evidence that translocated segments of chromosomes attempt non-homologous pairing with $X$ and $Y$ chromosomes during meiosis I (Lyon, 1966), which interferes with $X$ inactivation, resulting in a lethal genedosage effect on the germ cells (Forejt, 1982). Finally, the interactions of the translocation chromosomes with other parts of the nucleus may produce errors in meiosis and cell death (Chandley, 1984). Males with reciprocal X-autosome translocations can present with 
severe spermatogenic arrest which frequently results in azoospermia (Madan, 1983). In females, the translocated $\mathrm{X}$ segment containing $\mathrm{X}$-genetic loci is presumed to remain transcriptionally active because the $X$-inactivation elements have been removed from control of the translocated segment. The abnormal $\mathrm{X}$ inactivation of the translocated segment interferes with the genetic control of germ-cell progression, resulting in meiotic arrest at the primary spermatocyte stage (Lifschytz and Lindsley, 1972). Reciprocal Y-autosome translocations may result in aberrant spermatogenesis due to abnormal sex chromosome pairing. The most common Robertsonian translocation observed in infertile males is $\mathrm{t}(13 \mathrm{q} 14 \mathrm{q})$. Meiotic studies of infertile carriers of $\mathrm{t}(13 \mathrm{q} 14 \mathrm{q})$ and $t(14 q 21 q)$ reveal abnormal behaviour of the rearranged autosomes in meiosis during spermatogenesis causing infertility (Luciani et al., 1984; Rosenmann et al., 1985). The heterochromatic short arms of acrocentric chromosomes carry the nucleolar organizer regions (NOR) which, in addition to their function in rRNA synthesis, are required to associate with the sex vesicle. Thus, Robertsonian translocations that have lost their NOR can increase the likelihood of cell disruption and germ-cell death, thus decreasing fertility (Robez, 1986).

\section{Chromosomal inversions}

Inversions cause infertility by the following mechanisms. First, the mechanics and time constraints imposed by the meiotic machinery on the formation of a pairing loop can impede meiosis (Forejt, 1982). Second, single-sperm PCR studies of crossing over indicate that recombination is reduced within the pairing loop and this also leads to a breakdown of meiosis (Brown et al., 1998a). Third, when crossing over occurs in the pairing loop, unbalanced gametes can then ensue (Chandley et al., 1987).

\section{Supernumerary and marker chromosomes}

Supernumerary chromosomes are extra chromosomes that are not easily identified by normal cytogenetic means. Carriers of marker chromosomes are at risk of infertility due to meiotic arrest and instability (Chandley, 1984).

\section{Chromosome disorders: constitutional aneuploidy}

\section{Klinefelter syndrome $(47, X X Y)$}

Klinefelter syndrome (one in 1000 males) is generally associated with the karyotype $47, \mathrm{XXY}$ which can be in all cells (full-blown trisomy) or in 'mosaic' form. There are various extents of spermatogenic failure but males are generally sterile (Rives et al., 2000) unless they are mosaic. Even in cases of apparent full-blown trisomy, functioning germ cells have been shown to be XY (hence the patients are gonadal mosaics) and there is compelling evidence that the compromised testicular environment in these men leads to increased chromosome segregation errors. Hence, males with Klinefelter syndrome who reproduce are more likely to have aneuploid offspring (Mroz et al., 1999). The extra X chromosome originates in paternal meiosis I non-disjunction of the $\mathrm{XY}$ bivalent in $>50 \%$ of cases, about $40 \%$ in maternal meiosis I or II and, in the remainder, post-zygotically (Hassold et al., 1996). There is an association of increased maternal age in maternal meiosis I cases (Hargreave, 2000). Griffin et al. (1995) found a significant increase in the incidence of $X Y$ sperm disomy in relation to age, indicating that older men, like older women (but to a lesser extent), have an increased likelihood of producing 47,XXY offspring. The incidence of $X Y$ sperm disomy or paternally derived Klinefelter syndrome is associated with a failure of the $X$ and $Y$ to recombine during meiosis I (Hassold et al., 1991).

\section{$47, X Y Y$ males}

Present in one in 1000 male births, 47, XYY arises through paternal meiotic II non-disjunction of the $Y$ chromosome. This causes an aberrant hormonal balance in the gonadal environment which affects normal function of human chorionic gonadotrophin (Attanasio et al., 1982). Some spermatogenic impairment is usual (Skakkebaek et al., 1973). As with 47,XXY, fertile 47,XYY men are believed to be gonadal mosaics. This indicates that the loss of one $Y$ chromosome, followed by a process of germ-cell-line competition, in which $X Y$ cells have a selective advantage over aneuploid cells, is responsible for normal spermatocyte development (Melnyk et al., 1969).

\section{Turner syndrome}

A missing $X$ chromosome $(45, X)$ is the characteristic karyotype in Turner syndrome patients (frequency of about one in 5000 to one in 10000) and occurs in about $55 \%$ of cases (Steven et al., 1999). Streak gonads with hypoplasia and sexual infantilism due to the haplo-insufficiency of XY homologous genes crucial for gonadal development ensure complete sterility in most patients (Witters et al., 2001). The single $X$ chromosome is maternal in origin in $75 \%$ of cases. Thus, the predominant origin of $45, X$ is a spermatozoa with a missing sex chromosome and paternal meiotic nondisjunction at meiosis I or II or anaphase lag are the possible mechanisms for this (Hassold et al., 1988). In addition, double anaphase lag of the paternal $X$ or the $Y$ chromosome in a $46, X X$ or $X Y$ zygote could also result in a 45,X complement (Jacobs et al., 1997). Table 1 shows the relative frequencies of the many other karyotypes associated with Turner syndrome. Deletion 
Table 1. The relative frequencies of the karyotypes associated with Turner syndrome

\begin{tabular}{llc}
\hline Karyotype & \multicolumn{1}{c}{ Description } & $\begin{array}{c}\text { Frequency of Turner } \\
\text { cases (\%) }\end{array}$ \\
\hline $45, \mathrm{X}$ & One X chromosome missing & 55 \\
$46, \mathrm{X}, \mathrm{i}(\mathrm{Xq})$ (or one & Isochromosome X most commonly seen in \\
of its variants) & mosaic form together with a 45,X lineage & 20 \\
Various structural & For example deletions and ring X chromosomes & 10 \\
$46, \mathrm{XX} / 45, \mathrm{X}$ & Mosaic Turner or normal & 10 \\
Various Y mosaics & Mosaicism with one cell line having a normal Y & 5 \\
& or structurally rearranged $Y$ chromosome & \\
\hline
\end{tabular}

of $\mathrm{Xp}$ produces a greater number of Turner features than does deletion of $\mathrm{Xq}$.

\section{$47, X X X$}

Occurring in one in 1000 females, in $95 \%$ of cases the extra $\mathrm{X}$ chromosome is maternal in origin and associated with increased maternal age (Hassold et al., 1996). Most 47, XXX females are of normal weight, height and mental function, have normal pre-pubertal development and are fertile but have an early onset of menopause at about 30 years of age compared with the average of about 50 years of age (May et al., 1990). Increased dosage of genes that escape $X$ inactivation accounts for clinical features and individuals with four or more $\mathrm{X}$ chromosomes have been reported. Severity of symptoms increases in proportion with the number of $X$ chromosomes.

\section{Down syndrome (trisomy 21)}

Trisomy 21 is the leading cause of mental retardation in humans and occurs in an estimated one in 700 births. Affected females in rare cases can reproduce; however, most if not all, affected males are sterile: the phenotype includes spermatogenic arrest, reduction in the number of germ cells and hylinized tubules. The mechanism by which trisomy 21 affects male infertility remains unclear, but it is hypothesized that it may be due to a reduced proliferation of primordial germ cells during migration to the gonadal ridge, perhaps associated with an accelerated rate of apoptosis (Patrizio and Broomfield, 1999).

\section{Chromosome disorders: aneuploidy in the gametes}

\section{Maternal age effect for aneuploidy}

The most commonly cited relationship between genetics and reduced fecundity in women is the maternal age effect. Although usually discussed in terms of the risk of producing trisomic offspring (for example Down syndrome), the risk of trisomy associated with age is also the single most common factor in pregnancy loss. That is, approximately $25 \%$ of all first trimester spontaneous abortions are trisomic and it is likely that many other aneuploid conceptuses (for example the autosomal monosomies and trisomies of chromosomes 1 and 19) are lost before they reach the stage of clinical recognition. The dogma purported in many genetic texts to explain the maternal age effect is the so-called Production Line Hypothesis. This hypothesis, on the basis of observations by Henderson and Edwards (1968) in rabbit eggs, indicates that oocytes entering meiosis first are the first to be ovulated and those entering last are ovulated last. It is hypothesized that oocytes entering meiosis last are more prone to non-disjunction. However, a confounding issue is the fact that mammalian eggs enter meiosis and proceed to diplotene prenatally and only resume meiosis upon ovulation. In the current authors' opinion (and that of other authors) it is biologically implausible that events initiated before birth can have such profound effects on chromosome segregation many years later (for example, see Speed and Chandley, 1983; Griffin, 1996; Koehler et al., 1996). An alternative is the Local Factors Hypothesis (Crowley et al., 1979; Sugarawa and Mikamo 1983; Eichenlaub-Ritter et al., 1988), which indicates that extrinsic factors in the ovary associated with ageing affect the egg directly. That is, the ovarian environment becomes compromised as the woman ages and eggs within it become progressively less able to disjoin chromosomes normally. Changes in, for example, oxygen concentration, $\mathrm{pH}$ or hormone concentrations (all associated with ageing) have been implicated as subsequently affecting chromosome segregation in later meioses (Gaulden, 1992). Indeed, Van Blerkom and coworkers demonstrated that the spindle apparatus is less well-formed in eggs from older women which have a lower intracellular $\mathrm{pH}$ and are present in a more hypoxic environment (Van Blerkom et al., 1997; Van Blerkom 1998, 2000; Van Blerkom and Davis, 2001). The work of Hawley and co-workers has extended this hypothesis further by comparisons of non-disjunction of human chromosome 21 and the Drosophila NOD ${ }^{\text {DTW }}$ mutation (Hawley et al., 1994; Koehler et al., 1996). This led to the hypothesis that older eggs are less likely than younger eggs to segregate properly bivalents with distal chiasmata (or no chiasmata at all), whereas both older and younger 
oocytes have less difficulty segregating bivalents with proximal (or two) chiasmata. It is also hypothesized that a human homologue of the NOD gene product (a kinesinlike protein involved in maintaining contact between homologous chromosomes and between centromeres and kinetochores) plays a central role. However, to date, the lack of human material and few comparable mammalian systems have impeded the testing of this and other hypotheses including the Limited Pool Hypothesis (Peters and McNatty, 1980), which proposes that the depletion of oocytes in the ovary leaves the remainder more prone to non-disjunction.

\section{High proportions of chromosomally abnormal spermatozoa in infertile men}

Numerous authors have reported a correlation between the proportion of aneuploid spermatozoa (that is, spermatozoa with an extra or missing chromosome) in an ejaculate and severe defects in the conventional parameters of semen quality. That is, fluorescent in situ hybridization (FISH) studies indicate that severely infertile males may have $70 \%$ or more spermatozoa that are aneuploid (Bernardini, 1997; Lahdetie et al., 1997; Aran et al., 1999; Pang et al., 1999; Pfeffer et al., 1999; Shi and Martin, 2000; Ushijimal et al., 2000; Calogero et al., 2001). However, there have been reported cases where no such relationship is observed (for example Guttenbach et al., 1997). These discrepancies between studies may be due to differences among laboratories in scoring criteria but another possibility is that intrinsic (for example age or DNA polymorphisms) or extrinsic (for example environmental pollutants) factors play a role. Indeed, cigarette smoke, alcohol and chemotherapy regimens all cause increased sperm aneuploidy, whereas age has been clearly shown to be associated with increased sex chromosome sperm aneuploidy (for example Griffin et al., 1995; Robbins et al., 1997). It is hypothesized that the reduction or absence of recombination between the $X$ and $Y$ chromosomes is a common mechanism that explains the correlation between XY disomy and oligozoospermia (H. Tempest, D. Christopikou, M. Dalakiouridou, X. P. Zhai, S. Homa and D. K. Griffin, unpublished). Men with severely compromised semen parameters are usually treated by intracytoplasmic sperm injection (ICSI), which bypasses the normal barriers to fertilization. It is hypothesized that men treated by ICSI have an increased risk of producing trisomic offspring, especially for the sex chromosomes. Collectively, studies with patients who undergo ICSI have reported that 15 in 2084 patients show sex chromosome abnormalities; this is 5-10 times the published population frequency. However, no such associations have yet been reported for autosomal trisomy (Hassold et al., 1996; Bonduelle et al., 1999, 2002). Therefore, the question of whether males should be screened for sperm aneuploidy before treatment with
ICSI is the topic of considerable debate (Griffin et al., 2003).

\section{Y chromosome genes and microdeletions affecting fertility}

The AZF (azoospermia factor) region Yq11 contains genes vital for spermatogenesis. Vogt et al. (1996) and Affara et al. (1999) subdivided this region into AZFa, AZFb and AZFc. Deletions within these sub-regions cause various spermatogenic and infertility phenotypes (Affara and Mitchell, 2000) and represent about 10$15 \%$ of idiopathic azoospermia and oligozoospermia. For the most part, deletions in the AZFa region lead to Sertoli-cell only syndrome and azoospermia (or severe oligozoospermia). Deletions of AZFb and AZFc have a more diverse range of phenotypes.

Ma et al. $(1993 \mathrm{a}, \mathrm{b})$ isolated AZFb genes (RBM 1 and 2$)$ that were found to contain an RNA recognition motif and have homology to the RNA-binding protein superfamily. The absence of these genes leads to defects in RNA metabolism and processing. There are at least six subclasses of human RBM on the Y chromosome (RBMY1$R B M Y 6$ ) but only the $R B M Y 1$ sub-class is transcribed (Chai et al., 1997). The $R B M Y$ protein is localized to the nucleus, confined to germ cells, and also appears to be present at all stages of spermatogenesis except in elongating spermatids (Elliott et al., 1997).

In AZFC, the gene DAZ (deleted in azoospermia) contains an $\mathrm{N}$-terminal RNA binding motif and a series of repetitive amino acids (Reijo et al., 1995). This finding indicates a role for $D A Z$ as an RNA-binding protein concerned with RNA metabolism but its exact function, to the best of the current authors' knowledge, is yet unknown (Ferlin et al., 1999a). It is thought to be important in the control of spermatogenesis, as deletion of $D A Z$ is widely prevalent among infertile men. Moreover, there are now thought to be at least three copies of this gene within AZFc. It is difficult to determine the exact function of each copy; indeed it is uncertain whether each copy is expressed, because usually the whole cluster is deleted in infertile men. An autosomal homologue of $D A Z$ (DAZL1) has also been found in humans on chromosome $3 p ; D A Z L 1$ is expressed specifically in the testis and (to a lesser extent) in the ovaries (Saxena, 1996) and could be responsible for autosomal recessive forms of male infertility (Affara and Mitchell, 2000). Its role in spermatogenic control is supported by its homology to the Drosophila male infertility gene Boule, which, when mutated, causes spermatogenic arrest (Reijo et al., 1995; Ferlin et al., 1999a). The protein product is found mainly in post-meiotic germ cells affecting post-transcriptional control during the transcriptionally inactive stages of germ-cell differentiation. The DAZL1 protein in mice is expressed in the cytoplasm of the spermatocytes in pachytene, leptotene and zygotene stages but is not seen 


\section{Box 1. Summary of observations in men with deletions in the azoospermic factor (AZF) region}

Microdeletions are found almost exclusively in males with azoospermia or severe oligospermia

A higher frequency of deletions is seen in azoospermic men

Large deletions are generally associated with more severe spermatogenic defects

AZFa deletions (relatively uncommon) are generally associated with SCO (Sertoli-cell only syndrome)

AZFb and AZFc deletions (most common) may be associated with a variety of defects

in post-meiotic mouse germ cells (Ruggiu et al., 1997). Habermann et al. (1998) suggest that the DAZ transcripts are not immediately translated but are complexed to a non-translatable ribonucleoprotein fraction and stored until after meiosis and involved in transporting mRNA to various parts of a developing spermatozoon.

Deletions within the AZFa interval occur at a much lower frequency than for AZFb and AZFc. Candidate genes for infertility within this region include DFFRY, $D B Y$ and UTY (Mazeyrat et al., 1998; Ferlin et al., 1999b; Affara and Mitchell, 2000; Foresta et al., 2000). All three genes have ubiquitously expressed $X$ homologues. DFFRY (Drosophila fat facets related (on $Y$ chromosome)) encodes a ubiquitin-specific hydrolase which is involved in oocyte development in Drosophila (Brown et al., 1998b; Sargent et al., 1999) and is also involved in ubiquitin-dependent degradation of protein and specifically targets a transcription factor (D-jun) and other members of the signal transduction cascade involved in regulating (D-jun) activity. $D B Y$ (DEAD box $Y$ gene) encodes a protein containing the DEAD box motif found in RNA helicases and therefore may be involved in RNA metabolism. The function of UTY (ubiquitous transcribed tetrapeptide repeat gene on $Y$ chromosome) is currently unknown (Odorisio et al., 1996) but deletions in this gene have been found in both fertile and infertile men. It is in this region that the only point mutation on the $\mathrm{Y}$ chromosome that is associated with infertility has been found: a fourbase pair deletion in the splice site of DFFRY (Sun et al., 1999). Indeed, the predominant lesions in $Y$ chromosome are large deletions. The reasons for this are thought to be the large numbers of repeat sequences on the chromosomes causing unequal sister chromatid exchange (Blanco et al., 2000; Kuroda-Kawaguchi et al., 2001). This can lead to progressive rearrangements of the $\mathrm{Y}$ chromosome, a variable phenotype over time (or age effect) and subsequent problems in establishing genotype or phenotype correlations. The observations that have been made in men with deletions in the AZF region oligoszoopermia are summarized in Box 1. In general terms it is thought that differential removal of a range of genes leads to the different spermatogenic phenotypes. Indeed, many genes may be present in several copies and thus differential deletion of them may lead to dosage effects (Vogt et al., 1997; Affara and Mitchell, 2000).

\section{The CFTR gene and fertility}

\section{Cystic fibrosis and congenital bilateral absence of the} vas deferens

Cystic fibrosis (CF) is the most common fatal autosomal recessive disorder in Caucasians, with an incidence of one in 25 and a carrier frequency of one in 2400. It arises because of mutations in the cystic fibrosis transmembrane conductance regulator gene (CFTR; Hargreave, 2000). Infertility in males with a CFTR mutation is found to be due mainly to obstructive azoospermia (Sheynkin, 2000). The gene encodes for a membrane protein that functions as an ion channel and also influences the formation of the ejaculatory duct, seminal vesicle, vas deferens and distal two-thirds of the epididymis. The CFTR gene is expressed in the postnatal human epididymis, with the protein found in the luminal border of the human cauda epididymal epithelium. The CFTR protein is also involved in the transport of electrolytes and water across the epididymal epithelium, which helps to achieve an optimum environment for sperm maturation and transport (Pallares-Ruiz, 1999). This involvement in sperm maturation indicates that mutations in the CFTR gene may cause infertility not only through obstruction but also through deficiencies in sperm maturation. Genetic studies have revealed that $50-83 \%$ of patients with congenital bilateral absence of the vas deferens (CBAVD) have at least one known CFTR gene mutation and that approximately $10 \%$ have two known CFTR mutations (Donat et al., 1997). More than 95\% of men with CF have abnormalities in structures derived from the Wolffian duct. Although CBAVD is genetically similar to CF it is a clinically distinct disorder. It is found in $2 \%$ of men who present with infertility and is more commonly associated with obstructive azoospermia, low semen volume and acidic $\mathrm{pH}$ (Heaton and Pryor, 1998; Meschede et al., 1998). The most common cause of CBAVD seems to be a combination of the 5T allele in one copy of the CFTR gene which lacks exon 9, resulting in low expression of functional CFTR protein (Chu, 1991), and a CF mutation, the most common being $\Delta \mathrm{F} 508$, in the other copy (Chillon et al., 1995). CFTR mutations have been found in some men with congenital unilateral absence of the vas deferens, and this has led Chillon et al. (1995) to suggest that it could be an incomplete form of CBAVD. Men with this disorder appear to have normal fertility and are rarely diagnosed (Meschede et al., 1998). 
Table 2. Genes implicated in infertility

\begin{tabular}{|c|c|c|c|c|}
\hline Gene & Proposed function & Role in infertility & Comments & Reference \\
\hline CFTR & $\begin{array}{l}\text { Encodes for a membrane protein } \\
\text { that functions as an ion channel } \\
\text { and also influences the formation } \\
\text { of the ejaculatory duct, seminal } \\
\text { vesicle, vas deferens and distal } \\
\text { two-thirds of the epididymis }\end{array}$ & $\begin{array}{l}\text { Involved in congenital bilateral } \\
\text { absence of the vas deferens, } \\
\text { congenital unilateral absence } \\
\text { of the vas deferens, bilateral } \\
\text { ejaculatory duct obstruction } \\
\text { and Young syndrome }\end{array}$ & See text & $\begin{array}{l}\text { Heaton and Pryor, 1990; Chu et al., } \\
\text { 1991; Hirsh et al., 1993; Chillon } \\
\text { et al., 1995; Meschede et al., 1997, } \\
\text { 1998; Pallares-Ruiz, 1999; Sheynkin, } \\
\text { 2000; Meng et al., } 2001\end{array}$ \\
\hline$K A L I G-1$ & $\begin{array}{l}\text { Encodes a protein with homology to } \\
\text { neural cell adhesion molecule, } \\
\text { allowing normal migration of } \\
\text { GnRH neurones from their site } \\
\text { of embryonic origin in the medial } \\
\text { nasal placode to the hypothalamus }\end{array}$ & $\begin{array}{l}\text { Prevents the movement of } \mathrm{GnRH} \\
\text { to the hypothalamus during } \\
\text { development }{ }^{8} \text { and subsequent } \\
\text { testis failure. X-linked form of } \\
\text { Kallman syndrome results } \\
\text { from a mutation in this gene }\end{array}$ & $\begin{array}{l}\text { Variable penetrance regardless of the } \\
\text { inheritance pattern }\end{array}$ & Nudell and Turek, 2000 \\
\hline PTPN11 & $\begin{array}{l}\text { Encodes two Src homology } 2 \text { (SH2) } \\
\text { domains }{ }^{33} \text {. The protein encoded } \\
\text { is present in an active and inactive } \\
\text { conformation }\end{array}$ & $\begin{array}{l}\text { Responsible for just over half the } \\
\text { cases of Noonan syndrome }\end{array}$ & $\begin{array}{l}\text { Mis-sense mutations have been found } \\
\text { to affect the amino terminal } \mathrm{SH} 2 \\
\text { domain and the phosphotyrosine } \\
\text { phosphatase domains, resulting in } \\
\text { the protein being continually active. } \\
\text { Therefore, Noonan syndrome is due } \\
\text { to over activity of the proteins }{ }^{33}\end{array}$ & Tartaglia et al., 2001 \\
\hline SF1 & $\begin{array}{l}\text { A member of the nuclear receptor } \\
\text { family that regulates expression } \\
\text { of steroid hydroxylases }{ }^{34}\end{array}$ & $\begin{array}{l}\text { SF1 XY knockout mice do not have } \\
\text { adrenal glands and gonads. A } \\
\text { mis-sense mutation in the DNA } \\
\text { binding domain of } S F 1 \text { results } \\
\text { in an XY individual exhibiting } \\
\text { streak gonads and fully developed } \\
\text { Mullerian structures. }{ }^{37} \text { Possibly } \\
\text { in the Leydig cells where it } \\
\text { regulates production of steroid } \\
\text { hormones }^{36}\end{array}$ & $\begin{array}{l}\text { Resembles the fushi tarazu gene, } \\
\text { a Drosophila nuclear receptor } \\
\text { gene involved in development. Not } \\
\text { necessary for initial gonad develop- } \\
\text { ment but expressed during testis } \\
\text { differentiation }{ }^{34} \text {. Possibly expressed } \\
\text { in the bipotential gonad and Sertoli } \\
\text { cells regulating the expression of } \\
\text { anti-Mullerian hormone }\end{array}$ & $\begin{array}{l}\text { Parker, 1998; Roberts et al., 1999; Swain } \\
\text { and Lovell-Badge, 1999; } \\
\text { Veitia et al., } 2001\end{array}$ \\
\hline SOX9 & $\begin{array}{l}\text { A member of a family of } \\
\text { transcription factors that contain } \\
\text { an } S R Y \text {-related HMG box }(S O X)\end{array}$ & $\begin{array}{l}\text { Mutations in } S O X 9 \text { gene have been } \\
\text { found in individuals who are } \\
\text { chromosomally male but } \\
\text { phenotypically female. The } \\
\text { SOX9 protein is found in the } \\
\text { bipotential gonads then is not } \\
\text { seen thereafter in the developing } \\
\text { ovaries but is present in the } \\
\text { fully developed male gonads }\end{array}$ & $\begin{array}{l}\text { Mouse transgenic studies show that } \\
\text { female-to-male sex reversal occurs } \\
\text { when female mice carry Sox } 9 \text {. } \\
\text { Expression is upregulated in the } \\
\text { Sertoli cells shortly after Sry } \\
\text { expression, indicating that Sox } 9 \\
\text { is activated by } \operatorname{SrY}\end{array}$ & Clarkson and Harley, 2002 \\
\hline
\end{tabular}


Table 2. (Continued)

\begin{tabular}{|c|c|c|c|c|}
\hline Gene & Proposed function & Role in infertility & Comments & Reference \\
\hline$D A X 1$ & $\begin{array}{l}\text { A member of the nuclear hormone } \\
\text { receptor superfamily }\end{array}$ & $\begin{array}{l}\text { Thought to be responsible for congenital } \\
\text { adrenal hypoplasia and dosage- } \\
\text { sensitive sex reversal (caused by an Xp } \\
\text { duplication) in humans. Dax } 1 \\
\text { proteins are present in the early } \\
\text { genital ridge of both males and } \\
\text { females. Expressed at the same } \\
\text { time as } S r y^{3}\end{array}$ & $\begin{array}{l}\text { Sry and Dax } 1 \text { are antagonistic to } \\
\text { each other. Also interacts with } \\
\text { SF1, forming heterodimers with } \\
\text { SF1 and thereby preventing SF1 } \\
\text { from binding and activating } \\
\text { its target genes }\end{array}$ & $\begin{array}{l}\text { Swain et al., } 1998 \\
\text { Veitia et al., } 2001\end{array}$ \\
\hline$W T 1$ & $\begin{array}{l}\text { A zinc-finger protein that functions } \\
\text { as a transcription factor }{ }^{44}\end{array}$ & $\begin{array}{l}\text { Associated with Denys-Drash } \\
\text { syndrome and Frasier syndrome }\end{array}$ & $\begin{array}{l}\text { In Frasier syndrome XY males } \\
\text { develop as females and donor } \\
\text { splice mutations have } \\
\text { been found }\end{array}$ & Swain and Lovell-Badge, 1999 \\
\hline GATA4 & $\begin{array}{l}\text { GATA proteins are zinc-finger } \\
\text { proteins involved in transcription } \\
\text { that recognize a consensus DNA } \\
\text { sequence, }(\mathrm{A} / \mathrm{T}) \text { GATA }(\mathrm{A} / \mathrm{G}) \\
\text { (the GATA motif) }^{45}\end{array}$ & $\begin{array}{l}\text { Expressed in bipotential gonads of both } \\
\text { sexes and regulates AMH in males } \\
\text { after differentiation of the testis. } \\
\text { Expression in males continues } \\
\text { through to adulthood. Expressed in } \\
\text { the Sertoli cells during fetal and post- } \\
\text { natal development. Also expressed } \\
\text { in the Leydig cells until puberty } \\
\text { when it shows an increase } \\
\text { in expression that coincides with } \\
\text { testosterone production }\end{array}$ & $\begin{array}{l}\text { Increased expression during } \\
\text { FSH and testosterone } \\
\text { production indicates that } \\
\text { androgen action could } \\
\text { influence the expression } \\
\text { of GATA4. When testes } \\
\text { are treated with GnRH, } \\
\text { there is an increase } \\
\text { in the amounts of GATA4 } \\
\text { mRNA production }\end{array}$ & $\begin{array}{l}\text { Swain et al., } 1998 \\
\text { Swain and Narvez, } 1998\end{array}$ \\
\hline WTN4 & $\begin{array}{l}\text { Encodes secreted glycoproteins, } \\
\text { rich in cysteine residues that } \\
\text { function as signalling molecules. } \\
\text { Involved in transcriptional activation }\end{array}$ & $\begin{array}{l}\text { Deletions have been found to cause } \\
\text { male sexual development in } \\
X X \text { mice. Over-expression in } \\
\text { humans is thought to result in } \\
\text { XY sex reversal }{ }^{49}\end{array}$ & $\begin{array}{l}\text { During sex determination in } \\
\text { humans WNT4 upregulates } \\
\text { the expression of } D A X 1\end{array}$ & $\begin{array}{l}\text { Jordan et al., } 2001 \\
\text { Vilain, } 2002\end{array}$ \\
\hline$D M R T 1$ & $\begin{array}{l}\text { Male-specific gene that encodes } \\
\text { a protein with a conserved } \\
\text { zinc-finger-like DNA-binding } \\
\text { domain (the DM domain) }\end{array}$ & $\begin{array}{l}\text { Expressed in the genital ridge } \\
\text { of both sexes during early } \\
\text { development but to a greater } \\
\text { extent in males. Mice hetero- } \\
\text { zygous for Dmrt1 have normal } \\
\text { testes and are fertile but those } \\
\text { homozygous for the mutant Dmrt1, } \\
\text { missing the DM domain, show } \\
\text { incomplete testis development }\end{array}$ & $\begin{array}{l}\text { In mice, Dmrt1 is expressed } \\
\text { in spermatogonia, thereby } \\
\text { indicating a role in the } \\
\text { meiotic or mitotic cell } \\
\text { cycle. In mice with } \\
\text { mutations in Dmrt1, } \\
\text { the Sertoli cells have } \\
\text { abnormal morphology, } \\
\text { over-proliferate and die }\end{array}$ & $\begin{array}{l}\text { Raymond et al., } 2000 \\
\text { Zarkower, } 2001\end{array}$ \\
\hline
\end{tabular}




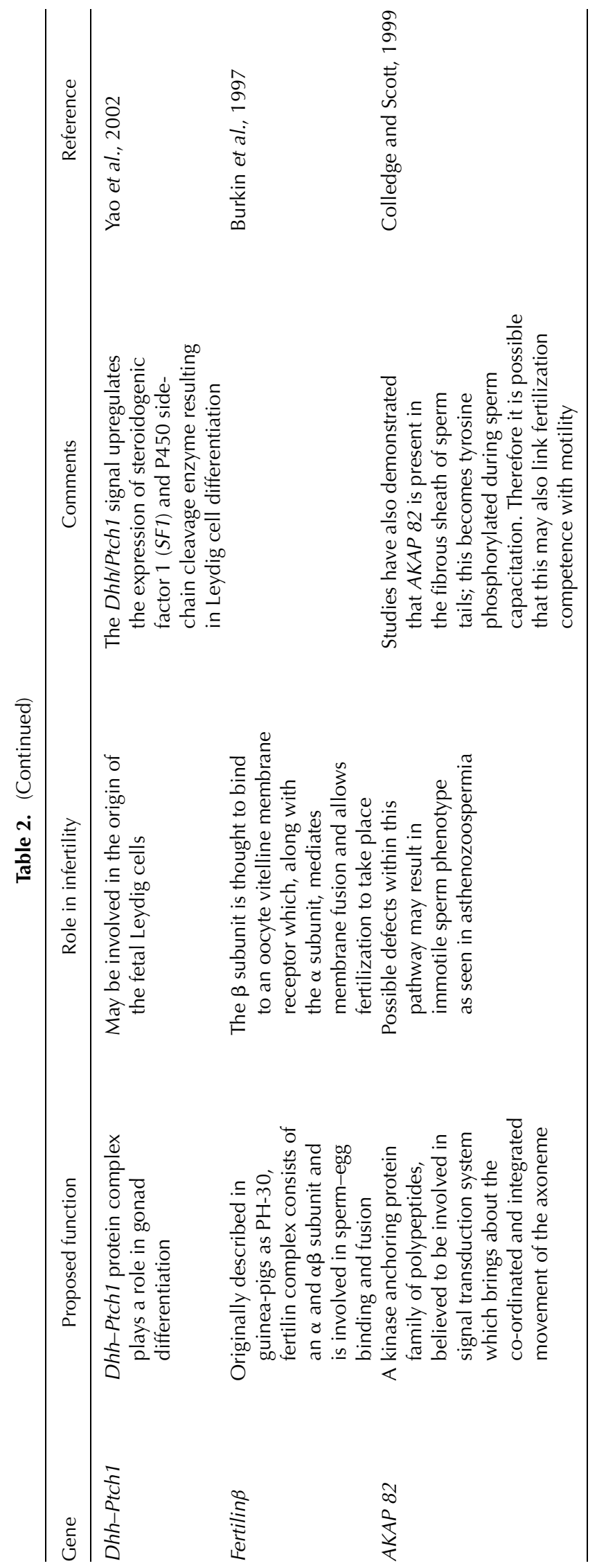

\section{Bilateral ejaculatory duct obstruction}

Bilateral ejaculatory duct obstruction (BEDO) is usually caused by infections, cysts or trauma. In cases with no obvious external cause CFTR mutation can occur. Meschede et al. (1997) carried out an analysis of the CFTR gene in a group of seven men with BEDO. They found that five were compound heterozygotes for either two different mutations or for a single mutation and a 5T allele. One was heterozygous for the R347P mutation.

\section{Young syndrome}

Young syndrome can cause a complete bilateral plugging of the epididymal lumen and result in azoospermia (Meschede et al., 1998). There is a single report that the prevalence of CFTR mutation $\triangle F 508$ was slightly higher in men with Young syndrome, though analysis of another group of men with Young syndrome did not provide evidence of any CFTR mutations (Hirsh et al., 1993; Meschede et al., 1998).

\section{Other genes implicated in infertility}

A list and comment on a number of genes that have been implicated in infertility is provided in Table 2 . Many of these genes have been isolated through model systems, for example in mice. Clearly, these model systems are essential tools to understand further the multifactorial nature of infertility. Table 2 highlights genes that, in general, have appeared frequently in the literature; however, to the best of the authors' knowledge, over 200 are now reported (Matzuk and Lamb, 2003). A more complete list can be found at http://www.nature.com/fertility.

Of particular interest is the androgen receptor gene in which a number of studies have reported an association between the length of the CAG repeat in exon 1 of the gene I and male infertility. For instance Casella et al. (2003) report an association between males with testicular failure (especially those with hypospermatogenesis) and a significantly elongated androgen receptor polyglutamine tract compared with controls. This is also reported in previous studies by, for example Misfud et al. (2001) and Yoshida et al. (1999). However, this finding has been challenged by a number of authors (for example Rajpert-De Meyts et al. (2002) and Van Golde et al. (2002)) who found no such association. Clearly, further work needs to be carried out to clarify the nature of any association.

\section{Further syndromes with a genetic basis affecting fertility}

\section{Prader-Willi syndrome and Angelman syndrome}

Prader-Willi syndrome is characterized by short stature, obesity, hypotonic muscles, mental retardation 
Table 3. Genetic syndromes associated with infertility

\begin{tabular}{|c|c|c|}
\hline Syndrome & Comments & Reference \\
\hline Non-classical adrenal hyperplasia & $\begin{array}{l}\text { Women have an increased risk of having children with genital abnormalities or life- } \\
\text { threatening metabolic crises if the father is a carrier }\end{array}$ & Hickey et al., 2002 \\
\hline Kallmann syndrome & $\begin{array}{l}\text { Also known as hypogonadotropic hypogonadism, can be sporadic or inherited in an X-linked, } \\
\text { autosomal dominant and autosomal manner. A heterogeneous genetic disorder } \\
\text { affecting one in } 10000-60000 \text {. Males predominate in a ratio of } 5: 1 \text { and the X-linked } \\
\text { form results from a deletion in the KALIG-1 (Kallmann interval } 1 \text { ) gene (Table 2) }\end{array}$ & Nudell and Turek, 2000 \\
\hline Immotile cilia syndrome & $\begin{array}{l}\text { A recessive disorder resulting in impaired or absent ciliary or flagellar motility. Characterized } \\
\text { by defects in both the microtubule and dynein arm assembly and is found in both } \\
\text { ciliary and sperm tail axonemes }\end{array}$ & Nudell and Turek, 2000 \\
\hline Noonan syndrome & $\begin{array}{l}\text { An autosomal dominant disorder, similar to Turner syndrome. Common features include } \\
\text { short stature, pulmonic stenosis, webbed neck testicular atrophy and cryptorchidism } \\
\text { affecting one in } 1000-2500 \text {. A heterogeneous syndrome with one gene (protein-tyrosine } \\
\text { phosphatase, non-receptor-type } 11 \text { (PTPN11)) so far discovered (Table 2) }\end{array}$ & Tartaglia et al., 2001 \\
\hline $\begin{array}{l}\text { Denys-Drash syndrome (DDS) } \\
\text { and Frasier syndrome }\end{array}$ & $\begin{array}{l}\text { DDS is characterized by severe genito-urinary malformations. Males with DDS seem to } \\
\text { be more severely affected than females exhibiting ambiguous or even female genitalia. } \\
\text { Heterozygous mutations in WT1 have been implicated (Table 1). In Frasier syndrome, } \\
\text { another disorder characterized by mutations in the WT1 gene, XY males develop } \\
\text { as females and donor splice mutations have been found }\end{array}$ & Swain and Lovell-Badge, 1999 \\
\hline Androgen insensitivity syndrome & $\begin{array}{l}\text { Also known as testicular feminization, there are a number of different forms including } \\
\text { non-sense mutations, point mutations and splice variants. Features include defective } \\
\text { spermatogenesis oligozoospermia, azoospermia and testicular atrophy as a } \\
\text { result of the dysfunction of the androgen receptor to the action of circulating androgens } \\
\text { affecting one in } 60000 \text {. An X-linked recessive syndrome }\end{array}$ & Patrizio and Broomfield, 1999b \\
\hline Polycystic kidney disease & $\begin{array}{l}\text { Affected patients present with multiple cysts in the liver, kidneys, epididymis and seminal } \\
\text { vesicles, affecting one in } 800 \text {. An autosomal dominant syndrome 16p13.3 PKD1 }\end{array}$ & Patrizio and Broomfield, 1999c \\
\hline Ushers syndrome & $\begin{array}{l}\text { Most common cause of inherited deafness and blindness, some patients also present with } \\
\text { degeneration of the sperm axoneme. Studies have revealed abnormal microtubular } \\
\text { organization of the axoneme in a number of cells including sperm tails resulting in } \\
\text { poor motility, and affecting an estimated one in 30,000. Autosomal recessive syndrome }\end{array}$ & Patrizio and Broomfield, 1999d \\
\hline
\end{tabular}


and hypogenitalism. These characteristics are caused by small deletions of an imprinted region of proximal chromosome $15 q$ of paternal origin or maternal uniparental disomy for chromosome 15 (Lalande, 1996). Most individuals with Prader-Willi syndrome do not reproduce. In Angelman syndrome (caused by deletion of the same region of maternal 15 paternal uniparental disomy 15), successful reproduction has been reported in only one case (Lossie and Driscoll, 1999).

\section{Polycystic ovarian syndrome}

Polycystic ovarian syndrome (PCOS) is associated with insulin resistance, defects in insulin secretion and a substantial risk of developing Type 2 diabetes mellitus. Defects in insulin-mediated receptor autophosphorylation have been found in a substantial proportion of women. Studies of 50 families of PCOS probands (Legro et al., 2002) indicate that $24 \%$ of sisters are affected with PCOS. There also appears to be an intermediate phenotype of sisters with regular menstrual cycles who are hyperandrogenic ( $22 \%$ of sisters).

\section{Myotonic dystrophy}

Mytotonic dystrophy (DM) is present in one in 10000 and the clinical features, in particular the variable age of onset and mode of inheritance (anticipation) are well described. The gene on chromosome 19 codes for a regulatory protein kinase found in skeletal muscle. Mistakes in faithful copying of the gene during gametogenesis result in the amplification (more rapid in male transmission) of a CTG triplet repeat and account for the variable age of onset and increased severity in subsequent generations (Brunner et al., 1993). Females with DM have clinical hyperandrogenism, which affects the hormones that control fertility; younger women are less severely affected (Cordray et al., 1994). Fertility of DM males can also be affected; Hortas et al. (2000) report that this is due to deficient capacitation and acrosome reactions in spermatozoa of DM patients. Hauser et al. (1991) also report that DM causes sclerosis of the tubuli seminiferi contorti, which can ultimately lead to azoospermia.

\section{Other syndromes}

Further genetic syndromes associated with infertility include non-classical adrenal hyperplasia, Kallmann syndrome, immotile cilia syndrome, Noonan syndrome, Denys-Drash syndrome and Frasier syndrome. These syndromes are summarized in Table 3.

\section{Conclusions}

Infertility is a broad term used to define a range of different phenotypes. The genetics of infertility is very complex and is dependent on different factors. Genetic factors can affect the production of the germ cells, the ability of the gametes to meet or embryonic development. Genetic disorders can be chromosomal, involve single genes or be multifactorial; however, these terms are not mutually exclusive. For instance, there are presumably many genes to be discovered that are involved in chromosome malsegregation associated with the maternal age effect. Perhaps studies of infertile men with high levels of sperm aneuploidy might shed further light on these. Reproduction is clearly a subject of intense interest and much research. There is great potential for new drug therapies and the improvement of current drug therapies. Treatment for infertility is unique in medicine as it offers individuals radical invasive treatment regimens that are of little or no benefit to the health of the individual being treated. Clearly the hope is that a greater understanding of the genetic control of infertility will bring low-risk treatment regimens that are effective and easy to administer.

The authors would like to thank N. Affara for his helpful advice in preparing this manuscript.

\section{References}

Affara NA and Mitchell MJ (2000) The role of human and mouse $\mathrm{Y}$ chromosome genes in male infertility Journal of Endocrinological Investigation 23 630-645

Affara NA, Wong J and Blanco P (1999) An exon map of the AZFc male infertility region of the human $\mathrm{Y}$ chromosome Mammalian Genome 10 57-61

Attanasio A, Blank B, Rager K and Gupta D (1982) Effect of human chorionic gonadotropin on the plasma levels of testosterone, estradiol, sex hormone binding globuline and free testosterone in Klinefelter syndrome Endokrinologie 80 129-134

Bernardini L, Martini E, Getaedts JP, Hopman AH, Lanteri S, Conte N and Capitanio GL (1997) Comparision of gonosomal aneuploidy in spermatozoa of normal fertile men and those with factor infertility detected by in situ hybridisation Molecular Human Reproduction 3431 438

Blanco P, Shlumukova M, Sargent CA, Jobling MA, Affara N and Hurles ME (2000) Divergent outcomes of intrachromosomal recombination on the human $Y$ chromosome: male infertility and recurrent polymorphism Journal of Medical Genetics $10752-758$

Bonduelle M, Camus M, De Vos A, Staessen C, Tournaye H, Van Assche E, Verheyen G, Devroey P, Liebaers I and Van Steirteghem A (1999) Seven years of ICSI and follow up of 1987 subsequent children Human Reproduction 14 243-264

Bonduelle M, Camus M, De Vos A, Staessen C, Tournaye H, Van Assche E, Verheyen G, Devroey P, Liebaers I and Van Steirteghem A (2002) Neonatal data on a cohort of 2889 infants born after ICSI (1991-1999) and of 2995 infants born after IVF (1983-1999) Human Reproduction 17671

Brown GM, Leversha $M$, Hulten $M$, Ferguson-Smith MA, Affara NA and Furlong RA (1998a) Genetic analysis of meiotic recombination in humans by use of sperm typing: reduced recombination within a heterozygous paracentric inversion of chromosome 9q32-q34.3 American Journal of Human Genetics 62 1484-1492

Brown GM, Furlong RA, Sargent CA, Erickson RP, Longepied G, Mitchell M, Jones MH, Hargreave TB, Cooke HJ and Affara NA (1998b) Characterisation of the coding sequence and fine mapping of the human DFFRY gene and comparative expression analysis and mapping to the Sxrb interval of 
the mouse $Y$ chromosome of the Dffry gene Human Molecular Genetics 7 97-107

Brunner HG, Brüggenwirth HT, Nillesen W, Jansen G, Hamel BC, Hoppe RL, De Die CE, Höweler CJ, van Oost BA and Wieringa B (1993) Influence of sex of the transmitting parent as well as of parental allele size on the CTG expansion in myotonic dystrophy (DM) American Journal of Human Genetics 53 1016-1023

Burkin HR, Burkin DJ, Davey PM, Griffin DK and Affara NA (1997) Mapping, sequence, and expression analysis of the human fertilin gene (FTNB) Genomics 40 190-192

Calogero AF, DePalma A, Grazioso C, Barone N, Rappazzo G and D'Agata $\mathbf{R}$ (2001) Aneuploidy rate in spermatozoa of selected men with abnormal semen parameters Human Reproduction 16 1172-1179

Casella R, Maduro MR, Misfud A, Lipshultz LI, Yong EL and Lamb DJ (2003) Androgen receptor gene polyglutamine length is associated with testicular histology in infertile patients Journal of Urology 169224 227

Chai NN, Salido EC and Yen PH (1997) Multiple functional copies of the RBM gene family, a spermatogenesis candidate on the $\mathrm{Y}$ chromosome Genomics 45 355-361

Chandley AC (1984) Infertility and chromsomal abnormality. In Oxford Reviews of Reproductive Biology Chapter 1 Vol 6 Ed. JR Clark. Oxford University Press, Oxford

Chandley AC, McBeath S and Speed RM (1987) Pericentric inversion in hyman chromosome 1 and the risk for male sterility Journal of Medical Genetics 24 325-334

Chillon M, Casals T, Mercier B, Bassas L, Lissens W, Silber S, Romey MC, Ruiz-Romero J, Verlingue C and Claustres M (1995) Mutations in the cystic fibrosis gene in patients with congenital absence of the vas deferens New England Journal of Medicine 332 1475-1480

Chu CS, Trapnell BC, Murtagh JJ, Jr, Moss J, Dalemans W, Jallat S, Mercenier A, Pavirani A, Lecocq JP and Cutting GR (1991) Variable deletion of exon 9 coding sequences in cystic fibrosis transmembrane conductance regulator gene mRNA transcripts in normal bronchial epithelium European Molecular Biology Organization 10 1355-1363

Clarkson MJ and Harley VR (2002) Sex with the SOX on: SRY and SOX9 in testis development Trends in Endocrinology and Metabolism 13 106111

Colledge M and Scott JD (1999) AKAP's: from structure to function Trends in Cell Biology 9 216-221

Cordray JP, Merceron RE, Siboulet B, Guillerd X, Nys P, Reboul P and Rainaut M (1994) Diagnostic strategy in infertility due to hyperandrogenism. Development of a decision tree Revue Francaise de Gynecologie et d'Obstetrique 89 245-254

Crowley PH, Gulati DK, Hayden TL, Lopez P and Dyer R (1979) A chiasma-hormonal hypothesis relating Down's syndrome and maternal age Nature 280 417-418

Donat R, McNeill AS, Fitzpatrick DR and Hargreave TB (1997) The incidence of cystic fibrosis gene mutation in patients with congenetal bilateral absence of the vas deferens British Journal of Urology 7974 77

Eichenlaub-Ritter U, Chandley AC and Gosden RG (1988) The CBA mouse as a model for age-related aneuploidy in man: studies of oocyte maturation spindle formation, and chromosome alignment during meiosis Chromosoma 96 220-226

Elliott DJ, Millar MR, Oghene K et al. (1997) Expression of RBM in the nuclei of human germ cells is dependent on a critical region of the $Y$ chromosome long arm Proceedings National Academy of Sciences USA 94 3848-3853

Ferlin A, Moro E, Onisto M, Toscano E, Bettella A and Foresta C (1999a) Absence of testicular DAZ gene expression in idiopathic severe testiculopathies Human Reproduction 14 2286-2292

Ferlin A, Moro E, Garolla A and Foresta C (1999b) Human male infertility and $\mathrm{Y}$ chromosome deletions: role of the AZF-candidate genes DAZ, RBM and DFFRY Human Reproduction 14 1710-1716

Forejt J, Crosignani PG, Rubin BL, Fraccaro M and Editors (1982) X-Y involvement in male sterility caused by autosome trans-locations: a hypothesis. In Genetic Control of Gamete Production and Function pp 261-273. Academic Press, New York

Foresta C, Moro E, Rossi A, Rossato M, Garolla A and Ferlin A (2000) Role of the AZFa candidate genes in male infertility Journal of Endocrinological Investigation 23 646-651

Gaulden ME (1992) Maternal age effect: the enigma of Down syndrome and other trisomic conditions Mutation Research 296 69-88

Griffin DK (1996) The incidence, origin and etiology of aneuploidy International Review of Cytology 167 263-296

Griffin DK, Abruzzo MA, Millie EA, Sheean LA, Feingold E, Sherman SL and Hassold TJ (1995) Non-disjunction in human sperm: evidence for an effect of increasing paternal age Human Molecular Genetics 4 $2227-2232$

Griffin DK, Hyland P, Tempest H and Homa ST (2003) Should men underoging ICSI be screened for chromosome abnormalities in their sperm? Human Reproduction 18 1-7

Guttenbach M, Martinez-Exposito MJ, Michelmann HW, Engel W and Schmid M (1997) Incidence of diploid and disomic sperm nuclei in 45 infertile men Human Reproduction 12 468-473

Habermann B, Mi HF, Edelmann A, Bohring C, Backert IT, Kiesewetter F, Aumuller G and Vogt PH (1998) DAZ (Deleted in Azoospermia) genes encode proteins located in human late spermatids and in sperm tails Human Reproduction 13 363-369

Handelsman DJ, Conway AJ, Boylan LM and Turtle JRI (1984) Young's syndrome. Obstructive azoospermia and chronic sinopulmonary infections New England Journal of Medicine 310 3-9

Hargreave T (2000) Genetic basis of male infertility British Medical Bulletin 3 650-671

Hassold T, Abruzzo M, Adkins K, Griffin D, Merrill M, Millie E, Saker D, Shen J and Zaragova $\mathbf{M}$ (1996) Humans: incidence, origins and eitiology Environmental Molecular Mutagens 28 167-175

Hassold TJ, Sherman SL, Pettay D, Page DC and Jacobs PA (1991) XY chromosome nondisjunction in man is associated with diminished recombination in the pseudoautosomal region American Journal of Human Genetics 49 253-260

Hassold T, Benham F and Leppert M (1998) Cytogenetic and molecular analysis of sex-chromosome monosomy American Journal of Human Genetics 42 534-541

Hauser W, Aulitzky W, Baltaci S and Frick J (1991) Increasing infertility in myotonia dystrophica Curschmann-Steinert: A case report European Urology 20 341-342

Hawley RS, Frazier JA and Rasooly R (1994) Separation anxiety: the etiology of nondisjunction in flies and people Human Molecular Genetics 3 $1521-1528$

Heaton ND and Pryor JP (1990) Vasa aplasia and cystic fibrosis British Journal of Urology 66 538-540

Henderson SA and Edwards RG (1968) Chiasma frequency and maternal age in mammals Nature 218 22-28

Hickey T, Chandy A and Norman RJ (2002) The androgen receptor CAG repeat polymorphism and X-chromosome inactivation in Australian Caucasian women with infertility related to polycystic ovary syndrome Journal of Clinical Endocrinology and Metabolism 87 161-165

Hirsh A, Williams C and Williamson B (1993) Young's syndrome and cystic fibrosis mutations $\Delta \mathrm{F} 508$ Lancet $\mathbf{3 4 2} 118$

Hortas ML, Castilla JA, Gil MT, Molina J, Garrido ML, Morell M and Redondo M (2000) Decreased sperm function of patients with myotonic muscular dystrophy Human Reproduction 15 445-448

Jacobs P, Dalton P, James R, Mosse K, Power M, Robinson D and Skuse D (1997) Turner syndrome: a cytogenetic and molecular study Analysis of Human Genetics 61 471-483

Jordan BK, Mohammed M, Ching ST, Delot E, Chen XN, Dewing P, Swain A, Rao PN, Elejalde BR and Vilain E (2001) Up-regulation of WNT-4 signaling and dosage-sensitive sex reversal in humans American Journal of Human Genetics 68 1102-1109

Koehler KE, Hawley RS, Sherman and Hassold T (1996) Recombination and nondisjunction in humans and flies Human Molecular Genetics $\mathbf{5}$ 1495-1504 
Kuroda-Kawaguchi T, Skaletsky H, Brown LG et al. (2001) The AZFC region of the $Y$ chromosome features massive palindromes and uniform recurrent deletions in infertile men Nature Genetics 29 279-286

Lahdetie J, Saari N, Ajosenpaa-Saari M and Mykkanen J (1997) Incidence of aneuploid spermatozoa among infertile men studied by multicolour FISH American Journal of Medical Genetics 71 $115-121$

Lalande M (1996) Parental imprinting and human disease Annual Review of Genetics 30 173-195

Legro RS and Strauss JF (2002) Molecular progress in infertility: polycystic ovary syndrome Fertility and Sterility 78 569-576

Lifschytz E and Lindsley DL (1972) The role of X-chromosome inactivation during spermatogenesis Proceedings National Academy of Sciences USA 69 182-186

Lossie AC and Driscoll DJ (1999) Transmission of Angelman syndrome by an affected mother Genetics in Medicine 1 262-266

Luciani JM, Guichaoua MR, Mattei A and Morazzani MR (1984) Pachytene analysis of a man with a $13 q ; 14 q$ translocation and infertility Cytogenetics and Cellular Genetics 38 14-22

Lyon MF and Meredith R (1966) Autosomal translocations causing male sterility and viable aneuploidy in the mouse Cytogenetics 5 335-354

Ma K, Inglis JD, Sharkey A, Bickmore WA, Hill RE, Prosser EJ, Speed RM, Thomson EJ, Jobling $\mathbf{M}$ and Taylor K (1993a) A Y chromosome gene family with RNA-binding protein homology: candidates for the azoospermia factor AZF controlling human spermatogenesis Cell 75 1287-1295

Ma K, Simpson E, Chandler P, Goulmy E, Hargreave T B and Chandley AC (1993b) Loss of the 'azoospermia factor' (AZF) on Yq in man is not associated with loss of HYA Human Molecular Genetics 2 469-471

Madan K (1983) Balanced structural changes involving the human X: effect on sexual phenotype Human Genetics $63216-221 \mathrm{~s}$

Matzuk MM and Lamb DJ (2003) Genetic dissection of mammalian fertility pathways Nature Cell Biology and Nature Medicine, Fertility Supplement s41-s49

May KM, Jacobs PA, Lee M, Ratcliffe S, Robinson A, Nielsen J and Hassold TJ (1990) The parental origin of the extra X chromosome in $47, X X X$ females American Journal of Human Genetics 46 754-761

Mazeyrat S, Saut N, Sargent CA, Grimmond S, Longepied G, Ehrmann IE, Ellis PS, Greenfield A, Affara NA and Mitchell (1998) The mouse $Y$ chromosome interval necessary for spermatogonial proliferation is gene dense with syntenic homology to the human AZFa region Human Molecular Genetics 7 1713-1724

Melnyk J, Thompson H, Rucci AJ, Vanasek F and Hayes S (1969) Failure of transmission of the extra chromosome in subjects with 47XYY karyotype Lancet 797-798

Meng MV, Black LD, Cha I, Ljung BM, Pera RA and Turek PJ (2001) Impaired spermatogenesis in men with congenital absence of the vas deferens Human Reproduction 16 529-533

Meschede D, Dworniczak B, Behre HM, Kliesch S, Claustres M, Nieschlag E and Horst J (1997) CFTR gene mutations in men with bilateral ejaculatory-duct obstruction and anomalies of the seminal vesicles American Journal of Human Genetics 61 1200-1202

Meschede D, Dworniczak B, Nieschlag E and Horst J (1998) Genetic diseases of the seminal ducts Biomedicine and Pharmacotherapy $\mathbf{5 2}$ 197-203

Mifsud A, Sim CK, Boettger-Tong H, Moreira S, Lamb DJ, Lipshultz LI and Yong EL (2001) Trinucleotide (CAG) repeat polymorphisms in the androgen receptor gene: molecular markers of risk for male infertility Fertility and Sterility 75 275-281

Miklos GLG (1974) Sex chromosomes and pairing and male infertility Cytogenetics and Cellular Genetics 13538

Mroz K, Carrel L and Hunt PA (1999) Germ cell development in the XXY mouse: evidence that $X$ chromosome reactivation is independent of sexual differentiation Developmental Biology 207 229-238

Nudell DM and Turek PJ (2000) Genetic causes of male infertility: current concepts Current Urology Reports 1 273-281

Odorisio T, Mahadevaiah SK, McCarrey JR and Burgoyne PS (1996) Transcriptional analysis of the candidate spermatogenesis gene Ube1y and of the closely related Ube1x shows that they are coexpressed in spermatogonia and spermatids but are repressed in pachytene spermatocytes Developmental Biology 180 336-343

Pallares-Ruiz N, Carles S, Des Georges M, Guittard C, Arnal F, Humeau C and Claustres $\mathbf{M}$ (1999) Complete mutational screening of the cystic fibrosis transmembrane conductance regulator gene: cystic fibrosis mutations are not involved in healthy men with reduced sperm quality Human Reproduction 14 3035-3040

Pang MG, Hoegerman SF, Cuticchia AJ, Moon SY, Doncel GF, Acosta AA and Kearns WG (1999) Detection of aneuploidy for chromosomes 4, 6, $7,8,9,10,11,12,13,17,18,21, \mathrm{X}$ and $\mathrm{Y}$ by FISH in spermatozoa from nine patients with OAT undergoing ICSI Human Reproduction 14 1266-1273

Parker KL (1998) The roles of steroidogenic factor 1 in endocrine development and function Molecular and Cellular Endocrinology 25 59-63

Patrizio P and Broomfield D (1999) Male Fertility and Infertility pp 164-173 Eds T Glover and C Barratt. Cambridge University Press, Cambridge

Peters H and McNatty KP (1980) The Ovary University of California Press, Berkeley

Pfeffer J, Pang MG, Hoegerman SF, Osgood CJ, Stacey MW, Mayer J, Oehniger S and Kearns WG (1999) Aneuploidy frequencies in semen fractions from ten OAT patients donating sperm for ICSI Fertility and Sterility 72 472-478

Rajpert-De Meyts E, Leffers H, Petersen JH, Andersen AG, Carlsen E, Jorgensen $\mathbf{N}$ and Skakkebaek NE (2002) CAG repeat length in androgenreceptor gene and reproductive variables in fertile and infertile men Lancet 359 44-46

Raymond CS, Murphy MW, O'Sullivan MG, Bardwell VJ and Zarkower D (2000) Dmrt1, a gene related to worm and fly sexual regulators, is required for mammalian testis differentiation Genes and Developmen 14 2587-2595

Reijo R, Lee TY, Salo P et al. (1995) Diverse spermatogenic defects in humans caused by $\mathrm{Y}$ chromosome deletions encompassing a novel RNA-binding protein gene Nature Genetics $10383-393$

Rives N, Joly G, Machy A, Siméon N, Leclerc P and Macé B (2000) Assessment of sex chromosome aneuploidy in sperm nuclei from 47, XXY and 46,XY/47,XXY males: comparison with fertile and infertile males with normal karyotype Molecular Human Reproduction 6107 112

Robbins WA, Meistrich ML, Moore D, Hagemeister FB, Weier HU, Casse MJ, Wilson G, Eskenazi B and Wyrobek AJ (1997) Chemotherapy induces transient sex chromosomal and autosomal aneuploidy in human sperm Nature Genetics 16 74-78

Roberts LM, Shen J and Ingraham HA (1999) New solutions to an ancient riddle; defining the differences between Adam and Eve American Journal of Human Genetics 65 933-942

Robez Z (1986) Meiotic association between the XY chromsomes and the autosomal quadrivalent of a reciprocal translocation in 2 infertile men, 46XY t(19:22) and 46XY t(17:21) Cytogenetics and Cellular Genetics 43 154

Rosenmann A, Wahrman J, Richler C, Voss R, Persitz A and Goldman B (1985) Meiotic association between the $X Y$ chromosomes and unpaired autosomal elements as a cause of human male sterility Cytogenetics and Cellular Genetics 39 19-29

Ruggiu M, Speed R, Taggart M, McKay SJ, Kilanowski F, Saunders P, Dorin J and Cooke HJ (1997) The mouse Dazla gene encodes a cytoplasmic protein essential for gametogenesis Nature 389 73-77

Sargent CA, Boucher CA, Kirsch S et al. (1999) The critical region of overlap defining the AZFa male infertility interval of proximal $\mathrm{Yq}$ contains three transcribed sequences Journal of Medical Genetics 36 $670-677$

Saxena R, Brown LG, Hawkins T et al. (1996) The DAZ gene cluster on the Y-chromosome arose from an autosomal gene that was transposed, repeatedly amplified and pruned Nature Genetics 14 292-299

Sheynkin YR (2000) Genetics of Male Infertility http://www.uhmc. sunysb.edu/urology/male_infertility/Genetics_of_male_infertility.htm 
Shi Q and Martin RH (2000) Aneuploidy in human sperm: a review of the frequency and distribution of aneuploidy, effects of donor age and lifestyle factors Cytogenetics and Cell Genetics 90 219-226

Skakkebaek NE, Hulten M, Jacobsen P and Mikkelson M (1973) Quantification of human seminiferous epithelium. II. Histological studies in eight $47 \mathrm{XYY}$ men Journal of Reproductive Fertility $\mathbf{3 2}$ 391

Speed PE and Chandley AC (1983) Meiosis in the foetal mouse ovary II. Oocyte development and age-related aneuploidy: does a production line exist? Chromosoma 88 184-189

Steven L, Gersen MB and Keagle L (1999) The Principles of Clinical Cytogenetics Humana Press, New Jersey

Sugarawa S and Mikamo K (1983) Absence of correlation between univalent formation and meiotic nondisjunction in the aged female Chinese hamster Cytogenetics and Cell Genetics 35 34-40

Sun C, Skaletsky H, Birren B, Devon K, Tang Z, Silber S, Oates R and Page DC (1999) An azoospermic man with a de novo point mutation in the Y-chromosomal gene USP9Y Nature Genetics 23 429-432

Swain A and Lovell-Badge R (1999) Mammalian sex determination: a molecular drama Genes and Development 13 755-767

Swain A and Narvez V (1998) Gonadal differentiation, sex determination and normal Sry expression in mice require interaction between transcription partners GATA4 and FOG2 Development 129 46274634

Swain A, Narvaez V, Burgoyne P, Camerino G and Lovell-Badge R (1998) Dax1 antagonizes Sry action in mammalian sex determination Nature 39 761-767

Tartaglia M, Mehler EL, Goldberg R et al. (2001) Mutations in PTPN11, encoding the protein tyrosine phosphatase SHP-2, cause Noonan syndrome Nature Genetics 29 465-468

Uehara S, Hashiyada M, Sato K, Sato Y, Fujimori K and Okamura K (2001) Preferential X-chromosome inactivation in women with idiopathic recurrent pregnancy loss Fertility and Sterility $\mathbf{7 6}$ 908-914

Ushijimal C, Kumasako Y, Kihaile P, Hirotsuru K and Utsunomiya T (2000) Analysis of chromosomal abnormailities in human spermatozoa usng multi-colour FISH Human Reproduction 15 1107-1111

Van Blerkom J (1998) Epigenetic influences on oocyte developmental competence: perifollicular vascularity and intrafollicular oxygen Journal of Assisted Reproductive Genetics 15 226-234
Van Blerkom J (2000) Intrafollicular influences on human oocyte developmental competence: perifollicular vascularity, oocyte metabolism and mitochondrial function Human Reproduction Supplement 2 173-188

Van Blerkom J and Davis P (2001) Differential effects of repeated ovarian stimulation on cytoplasmic and spindle organization in metaphase II mouse oocytes matured in vivo and in vitro. Human Reproduction $\mathbf{1 6}$ 757-764

Van Blerkom J, Antczak M and Schrader R (1997) The developmental potential of the human oocyte is related to the dissolved oxygen content of follicular fluid: association with vascular endothelial growth factor levels and perifollicular blood flow characteristics Human Reproduction 12 1047-1055

Van Golde R, Van Houwelingen K, Kiemeney L, Kremer J, Tuerlings J, Schalken J and Meuleman E (2002) Is increased CAG repeat length in the androgen receptor gene a risk factor for male subfertility? Journal of Urology 167 621-623

Veitia RA, Salas-Cortes L, Ottolenghi C, Pailhoux E, Cotinot C and Fellous M (2001) Testis determination in mammals: more questions than answers Molecular and Cellular Endocrinology 179 3-16

Vilain E (2002) Anomalies of human sexual development: clinical aspects and genetic analysis Novartis Foundation Symposium 244 43-53

Vogt PH (1997) Human Y chromosome deletions in Yq11 and male fertility Advances in Experimental Medicine and Biology 424 17-30

Vogt PH, Edelmann A, Kirsch S et al. (1996) Human $Y$ chromosome azoospermia factors (AZF) mapped to different subregions in Yq11 Human Molecular Genetics 5 933-943

Witters I, Moerman P, Louwagie D, Van Assche Frans-André, Migeon BR and Fryns JP (2001) Second trimester prenatal diagnosis of epignathus teratoma in ring $\mathrm{X}$ chromosome mosaicism with inactive ring X chromosome Annales de Génétique 44 179-182

Yao HH, Whoriskey W and Capel B (2002) Desert hedgehog/ Patched 1 signalling specifies fetal Leydig cell fate in testis organogenesis Genes and Development 16 1433-1440

Yoshida KI, Yano M, Chiba K, Honda M and Kitahara S (1999) CAG repeat length in the androgen receptor gene is enhanced in patients with idiopathic azoospermia Urology 54 1078-1081

Zarkower D (2001) Establishing sexual dimorphism: conservation amidst diversity? Nature Reviews, Genetics 2 175-185 